\title{
Blood donors in Montreal (Canada) : a typology based on their daily travel behaviours
}

Marie-Soleil Cloutier, Élianne Carrier and Johanne Charbonneau

\section{OpenEdition}

Journals

Electronic version

URL: https://journals.openedition.org/rfst/1185

DOI: $10.4000 /$ rfst. 1185

ISSN: 2492-3672

Publisher

Espaces et SOciétés (UMR 6590)

Electronic reference

Marie-Soleil Cloutier, Élianne Carrier and Johanne Charbonneau, "Blood donors in Montreal (Canada) a typology based on their daily travel behaviours", Revue francophone sur la santé et les territoires

[Online], Varia, Online since 14 June 2021, connection on 16 June 2021. URL: http://

journals.openedition.org/rfst/1185 ; DOl: https://doi.org/10.4000/rfst.1185

This text was automatically generated on 16 June 2021.

\section{(i)(2)}

La Revue francophone sur la santé et les territoires est mise à disposition selon les termes de la Licence Creative Commons Attribution - Pas d'Utilisation Commerciale - Partage dans les Mêmes Conditions 4.0 International. 


\section{Blood donors in Montreal (Canada) : a typology based on their daily travel behaviours}

Marie-Soleil Cloutier, Élianne Carrier and Johanne Charbonneau

\section{Background and Aim}

1 Blood agencies are always looking for new ways to recruit and retain blood donors. Accordingly, most research have looked at individual motivation to give blood, but very few of them have studied the mobility and the daily space-time constraints of blood donors as a way to explain why people give blood. The aim of this article is to study the activity-space of blood donors. More specifically, we aim at a better understanding of the donors' daily itinerary to be able to characterize their blood donation experience in their everyday life.

\section{Methods}

2 In order to respond to our objective, we collected data on site at blood drive in the Montreal region, in Canada. In collaboration with Héma-Québec, the Quebec blood agency, we were allowed to recruit participants after their donation for a quick survey (10-15 minutes). We used a direct questionnaire in which we asked participants several socio-demographic questions, following by the identification of all the destinations they visited prior to their visit at the blood collection site, and the ones they are planning to visit after the blood donation. Sites were identified by the address, postal codes (in known) or street intersections. We interviewed 199 participants at 18 sites between January and March 2015, including 17 apheresis donors that were subsequently excluded because of their particular donor situations, different from full blood donors. The previously mapped locations of all destinations were used to create 
standard deviation ellipse for participants who had more than three daily destinations $(n=166)$.

\begin{tabular}{l}
\hline ORIGIN (LOCATION \\
DESCRIPTION): \\
ADDRESS: \\
OTHER DETAILS: \\
\hline
\end{tabular}

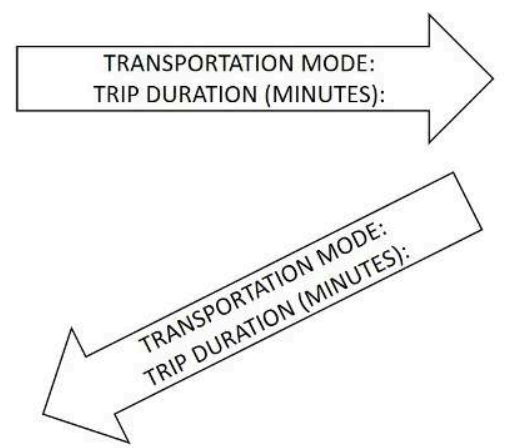

1ST LOCATION(DESCRIPTION):
ADDRESS:
ACTIVITY:
TIME SPENT THERE:
OTHER DETAILS:

\section{ND LOCATION}

(DESCRIPTION):

ADDRESS:

ACTIVITY:

TIME SPENT THERE:

OTHER DETAILS:

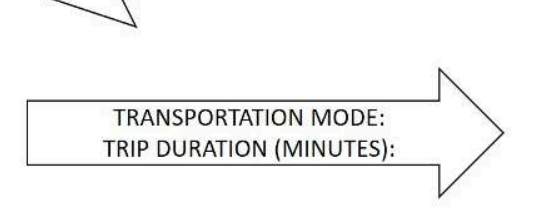

3RD LOCATION
(DESCRIPTION):
ADDRESS:
ACTIVITY:
TIME SPENT THERE:
OTHER DETAILS:

3 Then, a hierarchical clustering was calculated based on participants' sociodemographic data (age group, gender, employment status and having children living at home or not) and three variables from their activity-space the day of their donation (number of visited location, traveled distance and ellipse area).

\section{Results}

4 Statistical analyses were done on socio-demographics questions. In the sample, both sexes were almost equally represented (53\% women), as age group, even though the 50-64 years old group is more frequent (31\%). Most participants have a university degree (45\%) and are workers (60\%). Finally, half of participants have children (51\%) but only $29 \%$ of them have children still at home. Majority of participants gave blood at sites closed of their workplace/school or close to home (69\%). The second most common scenario is donors who made a specific trip to give blood (17\%) versus those who gave spontaneously (6\%). Seniors are more present in the group who did a specific trip to give blood and students tend to give more spontaneously. The variables chosen for the clusters created five groups of donors (see table 1 below). Donors of group A $(n=16)$ mainly traveled short distances on the day of their donation and $80 \%$ of this group gave blood close to their home or working/studying location. Donors of group B $(n=57)$ represents the generic participants with the average amount of daily destinations $(5,9)$ and traveled distance $(23,4 \mathrm{Km})$. Donors of group $C(n=9)$ are characterized by a small amount of daily destination and they mostly gave blood close to their home. Most donors are represented in group D ( $n=79)$ and are employed (91\%). They traveled larger distances and had multiples destinations (up to 7) on the day of their blood donation. In this group, $22 \%$ of donors did a specific trip to donate. The group $\mathrm{E}$ has only 5 participants who traveled the largest distance and had the most daily destinations. 


\begin{tabular}{|c|c|c|c|c|c|c|}
\hline & Group A & Group B & Group C & Group D & Group E & TOTAL \\
\hline $\mathbf{N}$ & 16 & 57 & 9 & 79 & 5 & 166 \\
\hline $\begin{array}{c}\text { Age } \\
\text { (mean) }\end{array}$ & 44 & 41 & 40 & 38 & 30 & 39,5 \\
\hline $\begin{array}{c}\text { Number of } \\
\text { location (mean) }\end{array}$ & 5,3 & 5,9 & 4,4 & 6,7 & 7,2 & 6,2 \\
\hline $\begin{array}{c}\text { Distance } \\
\text { travelled } \\
\text { (mean km) }\end{array}$ & 8,9 & 23,4 & 22,6 & 55,9 & 165,5 & 41,7 \\
\hline $\begin{array}{l}\text { Ellipse area } \\
\left(\text { mean } \mathbf{k m}^{2}\right)\end{array}$ & 0,8 & 6,5 & 0,2 & 58,6 & 875,4 & 56,6 \\
\hline Women (\%) & 69 & 51 & 56 & 49 & 80 & 53 \\
\hline $\begin{array}{c}\text { Children at } \\
\text { home } \\
\text { (\% yes) }\end{array}$ & 31 & 37 & 11 & 39 & 60 & 37 \\
\hline $\begin{array}{c}\text { Employment } \\
\text { status } \\
\text { (\% yes) }\end{array}$ & 75 & 79 & 89 & 91 & 60 & 84 \\
\hline
\end{tabular}

\section{Implications of results}

Our results show that donors tend to give blood close to a place that they were already going (shopping mall, work place, school, etc.). This is also coherent with results of previous studies on activity spaces showing that people tend to keep their destinations around a known path. Furthermore, the geographical ellipse of activity spaces tends to be wide in the area. We have urban or suburban ellipse in each of our group and the differences are more on the number of daily destinations than in the neighbourhood donors live in (urban or suburban). This research puts light on where and when donors tend to give blood in their daily routine and it was possible to create a typology of donors based on individual and geographical variables. Those results follow the idea that proximity between usual destinations and the blood drive is the main variable to consider when trying to reach blood donors.

\section{INDEX}

Keywords: Blood donation, daily mobility, activity space, hierarchical clustering, standard deviation ellipse 


\section{AUTHORS}

\section{MARIE-SOLEIL CLOUTIER}

Professeure agrégée, Institut National de la Recherche Scientifique

\section{ÉLIANNE CARRIER}

Agente de recherche, Institut National de la Recherche Scientifique

JOHANNE CHARBONNEAU

Professeure retraitée, Institut National de la Recherche Scientifique 